I UC STUDI ES

ISSN 1813-7733

Vol. - 4, December 2007

Published in April 2008 (p 7-24)

\title{
Managerial Leadership: An Islamic Perspective
}

\author{
Syed Mohammad Ather ${ }^{*}$ \\ Farid Ahammad Sobhani** $^{* *}$
}

\begin{abstract}
Islam is the guide to eradicate all problems in our social life. Allah (Swt) has addressed the believers as Ummah, which implies the necessity of leadership in Islam. Allah says to his Prophet Mohammad (Sm) “...I have perfected your religion for you, completed My favor upon you, and have chosen for you Islam as your religion" (Surah Al-Maidah). Mohammad (Sm) says "Every one of you is a shepherd and every one of you is responsible for what he is shepherd of" (Sahih Al Bukhari). Islam as a complete code of life has a set of principles, guidelines for managers to lead the human resources in an organization. This study is an attempt to find out the basic guidelines laid down in Islam for managerial leadership. It has pointed out the operational principles of managerial leadership, managerial grid theory, leadership continuum, team building- team spirit and qualities of a managerial leader from the Islam perspective.
\end{abstract}

\section{Introduction}

Allah (Swt) has created mankind with noble objective that people would lead their lives in peace and harmony following the tenets of His revelations sent down through Prophets from time to time since the very beginning of the society. Leadership is one of the core corners in our social activities (Patwary, 2003). It refers to a process of influencing and supporting others to work enthusiastically toward achieving objective (Koontz, 1994). It is a major factor for the success of any organization whether it is small or large, formal or informal. An effective leader is a must for attaining success in family life, business concern, government and political parties. Classically, managerial leadership is an approach of getting things done through others most

\footnotetext{
* Professor, Department of Management Studies, University of Chittagong

** Associate Professor, Department of Business Administration, IIUC
} 
effectively and efficiently in an organization. In view of Islam, leader is a member of a team who is given a certain rank and is expected to perform in a manner consistent with it. A leader leads a group who is expected to exercise influence in forming and accomplishing the ethical goals and objectives. The success of a leader is dependent on team building that leads to team spirit.

\section{Objectives of the Study}

In this article, the authors took interest to highlight the various aspects of managerial leadership from Islamic perspective. The rationale of the study lies in the fact that no unified research regarding managerial leadership in Islam has been undertaken. There are few studies in this line but hardly written from the Islamic management point of view.

The specific objectives of the study are:

i. To focus on the concept of managerial leadership;

ii. To distinguish between Western and Islamic Leadership;

iii. To identify the basic characteristics, principles and qualities of Islamic leadership;

iv. To examine the leadership styles especially 'Managerial Grid Theory' and 'Leadership Continuum' from Islamic points of view;

v. To justify 'Team Building and Team Spirit' under Islamic Managerial Leadership.

vi. To suggest a 'Model of Managerial Leadership from Islamic Perspective'

\section{Methodology}

This study is a desk-based and library-oriented research. To find out the development in managerial leadership and related Islamic issues, the authors consulted available literatures various publications, research monograms, journal and magazines in this field. The study has been structured in the light of the research objectives.

\section{Concept of Managerial Leadership}

There are different types of leadership as we see in our society political, societal and managerial. Ours is an age of managerial revolution. Everywhere we build organizations - offices, factories, banks, hospitals, schools, clubs etc. Organizations use rules, regulations, policy and strategy. Rules relate to the ways through 
which finance, operations, and marketing activities are regulated (Anisuzzaman et al, 1996). Strategies pave the ways to materialize the corporate objectives under the policy guidelines of the organization. Managerial leadership views an ability of a person to guide the efforts of many persons in achieving some objectives. It also refers to organizational leadership where two positions exist in an organization: Boss and Subordinate. Nowadays boss refers to leader and subordinate to followers. In fact, leadership involves three basic elements, viz.: (i) a leader who guides other persons; (ii) a group of followers who respond to such guidance; (iii) a situation or objectives to be achieved by coordinating the efforts of many persons. Thus the three basic elements - leader, followers and situation are crucial to the understanding of a leadership behavior (Ibid, 6).

In recent years, many theorists and practitioners have highlighted the difference between managers and leaders. What is important is to interpret leadership in terms of specific theoretical framework and to realize that leadership, however defined, make a difference (Luthans, 1995). Usually manager performs hierarchical role in an organization that is guided by the prescribed rules and regulations. But a leader takes attempts to change the rules and regulations if necessary and guide a group of people in carrying out organizational goals and objectives. Nowadays a manger tends to be a managerial leader, which is strongly supported by Islam. In a business setting, a manager is a leader when he or she possesses the quality of influencing upon his or her subordinates, colleagues, and superiors and to direct their work efforts towards the achievement of corporate mission and vision.

The differences between manager and managerial leader has been shown below:

a. The main function of a manager is to administer and control within the organizational hierarchy, while the main function of a managerial leader is to innovate something in order to develop organizational status in the competitive environment.

b. Managers focus on systems; structures; policies; and procedures of the organization, while the focal points of the managerial leaders are employees and staff.

c. Managers are usually liked by their superiors, while leaders are liked by their subordinates and peers. 
d. Mangers rely on control mechanism, but leaders rely on developing mutual trust.

e. Managers put their eyes on the bottom line, but leaders put their eyes on the horizon.

f. Managers have vertical relationship with their subordinates, while leaders have horizontal, vertical and diagonal relationship with their subordinates, followers, peers, and bosses.

g. Managers do the thing right, while leaders do the right thing.

h. Managers ask 'how' and 'when', while the leaders ask 'what' and 'why'.

i. $\quad$ Managers chair, while leaders lead.

Bennis has noted

"To survive in the twenty first century, we are going to need a new generation of leaders - leaders, not mangers. This distinction is an important one. Leaders conquer the context - the volatile, turbulent, ambiguous surroundings that sometimes seem to conspire against us and will surely suffocate us if we let them - while managers surrender to it.”

Obviously, the differences between managers and leaders are not scientifically derived, but it is probably true that an individual can be a leader without being a manger and a manager without being a leader.

(Ibid, p. 379-380)

\section{Western vs. Islamic Leadership}

There are a number of basic differences between Western and Islamic Leadership in an organization. Goals, traits, styles, decision-making process, methodology, nature, and participants are not similar between these two types of managerial leadership, which have been stated below:

\begin{tabular}{|l|l|l|}
\hline Points & Western Leadership & Islamic Leadership \\
\hline 1. Goals & $\begin{array}{l}\text { Solution of a problem by } \\
\text { groups, no reference to } \\
\text { Divine efforts. }\end{array}$ & $\begin{array}{l}\text { Seeking Allah's } \\
\text { pleasure in solving a } \\
\text { problem by group. }\end{array}$ \\
\hline 2. Participants & $\begin{array}{l}\text { Formal and informal leaders, } \\
\text { and rarely ordinary member }\end{array}$ & $\begin{array}{l}\text { Allah (Swt), Rasul } \\
\text { (Sm), the Leader and } \\
\text { the followers }\end{array}$ \\
\hline 3. Nature & Leadership is rule-bound and & Leadership relates to \\
\hline
\end{tabular}




\begin{tabular}{|c|c|c|}
\hline Points & Western Leadership & Islamic Leadership \\
\hline & $\begin{array}{l}\text { situational and no 'trusts' are } \\
\text { involved. }\end{array}$ & $\begin{array}{l}\text { 'trusts' which are to be } \\
\text { rendered back to the } \\
\text { participants. }\end{array}$ \\
\hline 4. Methodology & $\begin{array}{l}\text { Meetings, conference, study } \\
\text { reports, file orders etc. }\end{array}$ & $\begin{array}{l}\text { Consultation with the } \\
\text { followers especially } \\
\text { with those with relevant } \\
\text { knowledge, } \\
\text { memoranda, } \\
\text { notifications. }\end{array}$ \\
\hline 5. Traits & $\begin{array}{l}\text { Mundane knowledge, skill, } \\
\text { values as prescribed by } \\
\text { organizations }\end{array}$ & $\begin{array}{l}\text { Knowledge of Islamic } \\
\text { Shariah, individual } \\
\text { judgment, justice and } \\
\text { competence }\end{array}$ \\
\hline $\begin{array}{l}\text { 6. Decision } \\
\text { making }\end{array}$ & $\begin{array}{l}\text { With reference to rules of } \\
\text { business and no reference to } \\
\text { any Divine Law }\end{array}$ & $\begin{array}{l}\text { After consulting, the } \\
\text { leader must decide, but } \\
\text { put trust on Allah (Swt) }\end{array}$ \\
\hline $\begin{array}{l}\text { 7. Limitations } \\
\text { of leader }\end{array}$ & $\begin{array}{l}\text { Leaders seek leadership } \\
\text { without waiting for } \\
\text { leadership to come to them. }\end{array}$ & $\begin{array}{l}\text { Leaders must not seek } \\
\text { leadership; it must } \\
\text { come to them. }\end{array}$ \\
\hline $\begin{array}{l}\text { 8. Limitation of } \\
\text { followers }\end{array}$ & $\begin{array}{l}\text { Followers usually have a } \\
\text { passive role. }\end{array}$ & $\begin{array}{l}\text { Followers have an } \\
\text { active role to advise and } \\
\text { warn leadership of } \\
\text { consequences of policy } \\
\text { / action. }\end{array}$ \\
\hline $\begin{array}{l}\text { 9. Leadership } \\
\text { style }\end{array}$ & $\begin{array}{l}\text { Authoritative, let alone, } \\
\text { democratic as necessary }\end{array}$ & $\begin{array}{l}\text { A combination of } \\
\text { authoritarian and } \\
\text { democratic styles. }\end{array}$ \\
\hline $\begin{array}{l}\text { 10. Followers } \\
\text { style }\end{array}$ & $\begin{array}{l}\text { Responding to the leader's } \\
\text { call for advice and } \\
\text { cooperation with the leader, } \\
\text { but no acceptance of partial } \\
\text { responsibility. Both the } \\
\text { leaders and the followers are } \\
\text { primarily accountable to } \\
\text { organization. }\end{array}$ & $\begin{array}{l}\text { Responding to the } \\
\text { leader's call for advice } \\
\text { and cooperation with } \\
\text { the leader, and } \\
\text { acceptance of partial } \\
\text { responsibility for } \\
\text { action. Both the leaders } \\
\text { and the followers are } \\
\text { primarily accountable } \\
\text { to Allah (Swt) and } \\
\text { organization. }\end{array}$ \\
\hline
\end{tabular}

Source: Mohammad Anisuzzaman and Md. Zainal Abedin Majumder, Leadership: Western and Islamic - A Conceptual and Explorative Study, (Dhaka: Bangladesh Institute of Islamic Thought (BIIT), 1996), p. 49-50

\section{Characteristics of an Islamic Leadership}


Prophet Mohammad (Sm) said that the leader of a Jamaah (organization / community / nation) is their servant. Hence, a leader should be in the business of serving and helping others get ahead. Talib, Hisham Al (1991) identified some important characteristics of Islamic leadership, which are also applicable for the managerial leaders in an organization.

a. Allegiance:

The Islamic managerial leader is bound in allegiance to Allah.

b. Global Islamic Goals:

The leader perceives the goals of an organization not only in term of the interests of the group, but also in terms of wider Islamic objectives.

c. $\quad$ Adherence to Shariah and Islamic Manners:

The leader must adhere to Islamic injunctions. He can only continue his office as long as he observes the principles of Shariah. His behavior must conform to Islamic manners.

d. Delegated Trust:

Islamic leadership is a position with divine trust. He must enjoy this trust with highest degree of responsibility. Allah says, "Those, who, if we give them power in the land, establish Salat and pay Zakah and enjoin the right and forbid the wrong, with Allah rests the end of affairs" (Surah Al Hajj)

\section{Operational Principles of Islamic Managerial Leadership}

Islam does not permit any Muslim to live without having a leader in any situation even if they are on a trip or in a desert. The primary duties of a leader are to lead the people in offering prayers, to look after their interest with justice and run their activities in a disciplined and systematic way (Ahmad, 2006). However, an Islamic managerial leader will serve his followers or subordinates under some distinctive principles, out of which some distinct operational principles are mentioned below:

\section{i. Shura}

Managerial leaders in Islam must consult with their people before making any decision. It is also the fundamental aspect of democratic system. Managers in an organization must consult with their subordinates in formulating any strategy or policy. Allah (Swt) directed his Prophet (Sm) to consult with his companions. Allah says "And those who have answered the call of their lord and establish 
prayer and who conduct their affairs by consultation and spend out what we bestow on them for sustenance.” (Surah Al Shura, Verse-38). Allah also says "And by the mercy of Allah, you dealt with them gently. And had you been severe or harsh-hearted, they would have broken away from about you; so pass over (their faults), and ask for (Allah's) forgiveness for them; and consult with them in affairs. Then when you have made a decision, put your trust in Allah." (Surah AlImran, Verse-159)

\section{ii. Freedom of Thought}

Islam encourages freedom of thought. Practicing managers or executives should create such an environment in the organization so that the staff members can easily opine on any issue. The Four Khalifs of Islam considered this as an essential element of their leadership (Patwary, 2003). Hazrat Umar (R) praised Allah (Swt) that there were people in the Ummah who would correct him if he went astray.

\section{iii. Sources of Islamic Jurisprudence}

There are four sources of Islamic Jurisprudence. These are: Quran, Hadith, Izmah, and Kias. In managing any activity, the managers first look to its hints for solution from the Holy Quran. If hints are not available, he should give a second search of Hadith. Again if the solutions are not found in Hadiths, he should look to Izmah and Kias of recognized religiously learned persons and his good conscience.

\section{iv. Justice}

The management leaders must behave with team members justly and fairly without any discrimination regardless of their race, color or religion. Islam always urges for doing justice to all. The Qur'an commands Muslims to be fair and just in any circumstances even if the verdict goes against their parents or themselves. Allah says

"O you, who believe! Stand out firmly for justice, as witness to Allah, even as against yourselves or your parents or your kin and whether it be against rich or poor, for Allah protects both”.

(Surah An-Nisa, Verse-135)

\section{v. Dependence on Allah}

The managerial leaders in Islam must depend on Almighty Allah (Swt) for the outcome of any action. It is known in Islam as Tawakkul. Allah asked his believers to depend on Him. Allah says, “ .....when you have made a decision, put your trust in Allah, certainly, Allah loves those 
who put their trust (in Him)” (Surah Al-Imran, Verse-159). However, dependence on Him without any endeavors is not supported by Islam. The mangers must prepare managerial plans and policies in order to achieve the rational (halal) objectives. But he must depend on Allah (Swt) for the success of his plan.

\section{vi. Accountability}

Islam teaches accountability as vital component of management. The managers must be accountable for their duties and responsibilities to the Board of Directors. The Board must be accountable to the beneficiaries or stakeholders. According to Islam, each and every human being will be made responsible for his good or bad deeds and accordingly he will be rewarded or punished. Allah says

“...whosoever does good equal to the weight of an atom (or a small ant) shall see it. And whosoever does evil equal to the weight of an atom (or a small ant) shall see it." (Surah Az-Zilzal,Verse- 7-8 )

\section{vii. Sincerity}

An Islamic managerial leader must be sincere enough to achieve the objectives of an organization. The Qur'anic terminology of sincerity is Khulusiat. The Holy Quran urges people to be utmost sincere in his praying, meditations, and good deeds.

\section{viii. Dignity of Labor}

Islamic leaders must recognize the dignity of labor. Mohammad (Sm) says, "Pay the wages to the labor before his sweat dries up" (Al Hadith). Islam pointed out that earning as the best, which is earned by the toil of the labor. Hence, practicing managers should duly recognize the dignity of all categories of efforts especially physical labor of the workers and employees.

\section{ix. Esprit de corps}

The managerial leaders must try to achieve organizational goals and objectives with team rather than individual endeavors. The highest level of unity should be maintained among the executives, staff and workers for motivating and energizing team works. Islam encourages esprit de corps i.e. team efforts. Prophet Mohammad (Sm) says "The Hand of Allah is with the Jama'ah (team)" (Sunon Al Tirmidhi). (Ather, 2006)

\section{Underlying Qualities of a Leader in Islam}


The managerial leaders have to work with the human resources through team building and team spirit. In fact, it is a very tough job to develop a team \& team spirit in an organization. Unless or until a leader possesses a variety of skills, he will be facing many problems in managing human resources. Meredith et al (2000) pointed out some important project management skills relating to communication, organization, team building, leading, copying, and technology. The same skills are also required for a managerial leader. On the contrary, an Islamic leader must possess two fundamental skills, which are (i) Islamic character \& behavioral competence and (ii) Islamic \& professional knowledge. Other qualities required for an Islamic managerial leader has been mentioned below:

\begin{tabular}{|l|l|ll|}
\hline $\begin{array}{l}\text { SL. } \\
\text { No. }\end{array}$ & Classified Skills & Focal Points & \\
\hline 1 & Team building skills & $\begin{array}{l}\text { a) Empathy } \\
\text { c) Cohesion }\end{array}$ & $\begin{array}{l}\text { b) Motivation } \\
\text { d) Esprit de corps }\end{array}$ \\
\hline 2 & Leading competence & $\begin{array}{l}\text { a) Sets an example } \\
\text { c) Energetic } \\
\text { e) Positive }\end{array}$ & $\begin{array}{l}\text { b) Vision } \\
\text { d) Delegates authority } \\
\text { f) Initiating }\end{array}$ \\
\hline 3 & Ethical competence & $\begin{array}{l}\text { a) Morally sound } \\
\text { c) Justice }\end{array}$ & $\begin{array}{l}\text { b) Unbiased / impartial } \\
\text { d) Logical }\end{array}$ \\
\hline 4 & Communication skills & $\begin{array}{l}\text { a) Listening } \\
\text { c) Persuading } \\
\text { e) Punctual }\end{array}$ & $\begin{array}{l}\text { b) Dispatching } \\
\text { d) Convincing } \\
\text { f) Regular }\end{array}$ \\
\hline 5 & Organizing capacity & $\begin{array}{l}\text { a) Planning } \\
\text { c) Standard setting } \\
\text { e) Expediting }\end{array}$ & $\begin{array}{l}\text { b) Goal setting } \\
\text { d) Analyzing }\end{array}$ \\
\hline 6 & Coping skills & $\begin{array}{l}\text { a) Flexibility } \\
\text { c) Patience } \\
\text { f) Contemporary knowledge }\end{array}$ \\
\hline
\end{tabular}

Source: Developed by the authors

\section{Team Building under Islamic Leadership}

A team is not a random collection of individuals with different agenda. A dozen of individuals in a restaurant by random chance are not a group although they may be interacting, have a common goal of eating and drinking and be aware of each other. Teamwork does not just happen. It has to be organized and nourished through effective leadership and management (Altalib, H., 1991). Working together with team spirit is an Islamic directive. It is said in Hadith "The Hand of Allah is with the team (Jama'ah). Then, whoever singles himself out (from the Jama'ah) will be singled out for the Hell-Fire” (Sunon Al 
Tirmidhi). A team from Islamic point of view may be defined as a group of people under a team leader who work together on a continuing mission with common (halal) goals and objectives. The figure- 1 is a diagram where people designate A, B, C, P, Q, X, Y, and $\mathrm{Z}$ are working together under a team leader ' $\mathrm{M}$ ' to achieve organizational goal considering Islamic values. Here the team members are mutually interactive and connected with their leader. The goal is accomplished through specific and defined tasks that may be simultaneous or sequential and may change from time to time. A large team may be divided into sub-teams. Everyone in the team is expected to take responsibility for the success of the team as a whole. The work and performance of each member and of the whole team must relate to clearly defined objective. While each team member contributes particular skills and knowledge, the team as a whole, as well as each member, is responsible for the task on which it is focused.

Figure: 1 - A Diagram of Team Building under Islamic Leadership

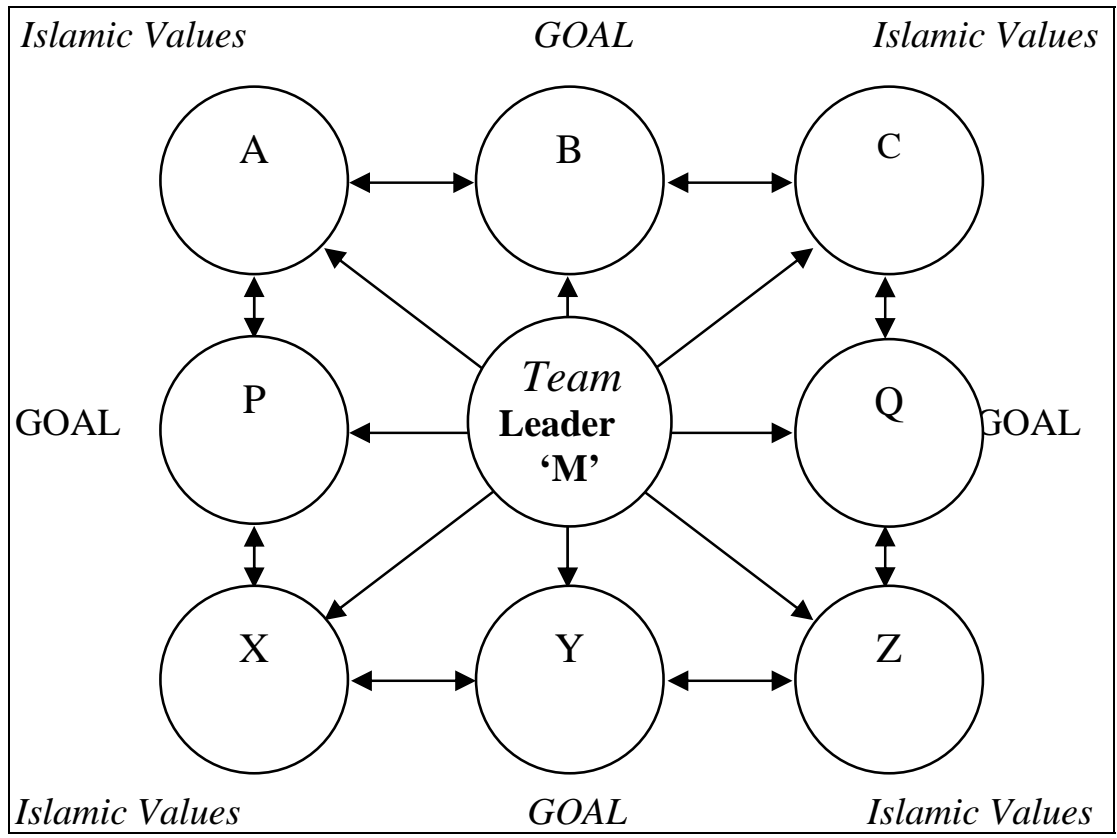

Source: Developed by the authors

Team building refers to creating and development of cohesion in the team. Esprit de corps is the ultimate organizational outcome of team building. Team spirit requires much more than knowledge, sincerity, dedication, and sacrifice. It is nourished by much higher level of 
understanding, appreciation and tactics. It functions among individuals who are ready to sacrifice their own personal differences and learn how to work with others coherently.

Team building encourages team members to examine how they work together, identify their weaknesses and develop more effective ways of cooperation. Keith Davis et al (2001) identified the following steps in a team building process:
a. Identification of a problem
b. Collection of relevant data
c. Data feedback and confrontation;
d. Problem solving experience
e. On the job application and follow-up.

Altalib et al (1996) stated team functions at all levels, but is most useful at the top level of management. Effectiveness at this level rests on a clear understanding of, and commitment to, what the task is and who has responsibility. Team spirit at the strategic level of management reflects on the other levels - tactical and operational.

Adhering to certain basic rules helps team to succeed. For example:

(i) The team member with primary responsibility in a given area determines, and is expected to make, the final decision.

(ii) Conversely, a member does not make decisions with regard to matters for which he does not have primary responsibility.

(iii) Team members do not undermine each other publicly even if they do not like one another, or disagree on issues and opinions.

(iv) A team is different from a committee, which makes decisions by voting. The team leader leads, rather than chairs, the efforts.

(v) A team has systematic and intensive communication links among its members.

The main shortcoming of teamwork in our society is the pervasive feeling that unless we agree with a person $100 \%$, we can't work with him or her. Hence, very few groups are working harmoniously. In most of the cases, one person tries to dominate and dictate his way of thinking and approach on the group. Many private institutions are victims of one-man management styles. How can a nation progress with this kind of mentality? We should realize that every one is different. It hardly exists in reality to find $100 \%$ similarities between two persons. We should remember that 'If two people always agree 
with one another, you need only one of them'. However, we have about $90 \%$ areas of common agreement among ourselves. We should make these agreements as the foundation of our cooperation. Today we make the $10 \%$ of difference a strong foundation for our disunity.

No mankind is perfect in this world. We shall not find any leader or team member who is devoid of all shortcomings except Prophets. Everybody has strengths and weaknesses. Islam encourages focusing on individual's strong points and putting aside the weak points. This may be the team spirit equation of the total group. It is essential to generate a new attitude within us, which is to focus on the strengths of our colleagues and subordinates and minimize their weaknesses. Such an attitude is a necessary condition for team development and team spirit.

\section{The Managerial Grid Approach - from Islamic Leadership viewpoint}

A well-known approach to defining leadership styles is the managerial grid (Keith Davis, 2001). The managerial grid is so far the most popular approach to help teach managers about leadership. Not only does this approach combine important contributions from other research, but also it provides information and convenient 'shorthand' for managers to use in communicating about their potential leadership styles and those of others (Talib, Hisham Al, 1991). Three largely parallel sets of leadership studies were conducted in the mid of 1940s at the Ohio State University and the University of Michigan. It was an attempt to determine what leader behavior was meaningfully associated with organization productivity. The studies under the initial leadership of Ralph Stogdill at Ohio State and of Rensis Likert at the University of Michigan, concluded that there were two principaldimensions of leadership behavior:

\section{a. Concern for people:}

This dimension is mostly 'staff and commitment oriented'. It involves a manger's concern for developing mutual trust with subordinates and followers, promoting two-way communication, being sensitive to their feelings and ideas. Managers with this concern are often characterized by their concern for welfare, commitment, friendliness, approaches and attitudes towards solidarity.

\section{b. Concern for production:}

This dimension is mostly 'job and task oriented'. It involves a manager's concern for actively directing subordinates in order to get the task done effectively and efficiently. The managers under this 
category are characterized by concern for completing the task as per plan, implementing rules, regulations, policies and procedures.

Research on the importance of these two dimensions has given useful information. For example, managers who worked in manufacturing concerns and who exhibited high concerns for productivity and low concern for employee were rated by their superiors as more proficient than more people oriented managers. On the contrary, service organizations, the most highly rated managers were those with a high concern for employees and a low concern for production.

The success of the studies led to the development of a matrix method for depicting managerial leadership styles. Developed by Robert Blake and Jane S. Mouton, the managerial grid enables us to identify a wide range of styles that represents various combinations of concern for people and concern for production.

Figure: 2 - Managerial Grid (Adapted)

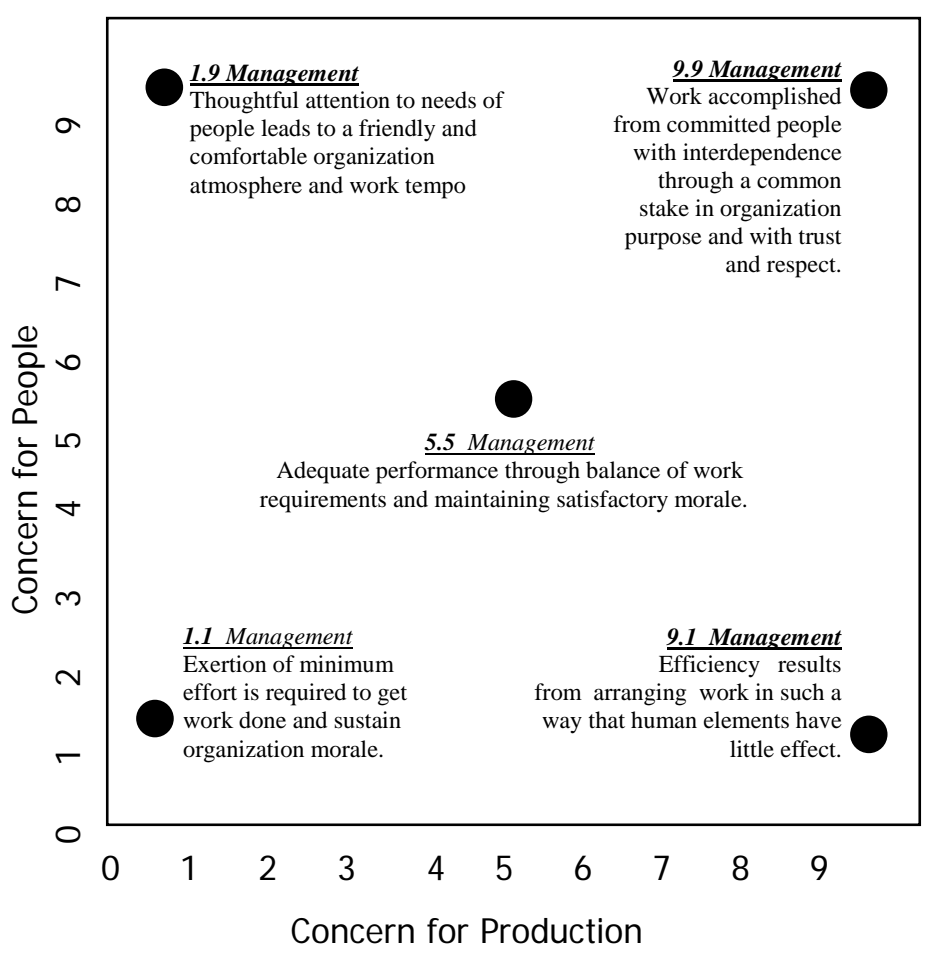

Source: Originally by Blake and Mouton, 1994 from Fred Luthans, Organization Behavior, New York, McGraw Hill Inc. 1995, p. 415 
As shown in the above Figure-2, a manager is rated on two 9-point scales to indicate the extent to which the managers demonstrate concern for each of the two central leadership dimensions: concern for people and concern for productivity. When these two scores are plotted on coordinates axes, their points on intersection falls on a grid of $(9 \mathrm{x}$ $9)=81$ possible points. This point is then used as a basis for comparing the manager's concern in the same manner. Of course, an attempt to define every point of 81 positions on the grid is impossible, briefly five extreme positions have been explained as under:

a. Impoverished leadership (1.1): This position characterizes managers who place low priority on both concern for people and concern for productivity. This sort of manager is clearly never treated as leader in a positive sense and at best serves as 'place keeper' until the group's problems can be attended to seriously.

b. Country club leadership (1.9): This position characterizes managers with high concern for people and low concern for production. Managers at 1.9 position are well liked by their subordinates as they try to enhance the job satisfaction of the employees.

c. Middle of the road leadership (5.5): This position characterizes managers who place moderate priority both on a concern for people and productivity. Managers at 5.5 level are steady, dependable, unlikely to deviate from previous patterns or traditional performance levels.

d. Autocratic leadership (9.1): The position characterizes managers with high concern for productivity and low concern for people. Managers at 9.1 position tend to be extremely conscientious, hardworking, loyal, responsible, and personally capable.

e. Team leadership (9.9): This position characterizes managers who place priority on both concern for people and concern for production. They think that the best way to have an excellent production plan is to team building and team spirit and to involve all stakeholders in decision-making process, which, in turn, leads to heightened levels of employee commitment. Blake and Mouton hesitate to claim that any one leadership style is superior in all cases, but in 'typical' business situations, the 9.9 style is preferable to all others.

Islam supports high productivity and high involvement of employees in an organization. Hence, from Islamic point of view, 9.9 style may be the target as an ideal leadership to become successful in managerial 
leadership. Islam also supports 5.5 style of leadership. But Islam does not support 1.1 and 1.9 styles of leadership as these encourage low productivity in an organization. On the other side, 9.1 cannot be accepted as employees' opinion is not considered at all in this style of managerial leadership.

\section{An Islamic Outlook of Leadership Continuum}

The latest development in leadership styles is the leadership continuum. The theory of leadership continuum is developed by Rober Tannenbaum and Warren H. Schmidt. Instead of suggesting a choice between the two styles of leadership - authoritarian or democratic, the leadership continuum assumes variety of styles, ranging from highly boss-centered to highly subordinate centered, with no suggestion that one is always right and another is always wrong.

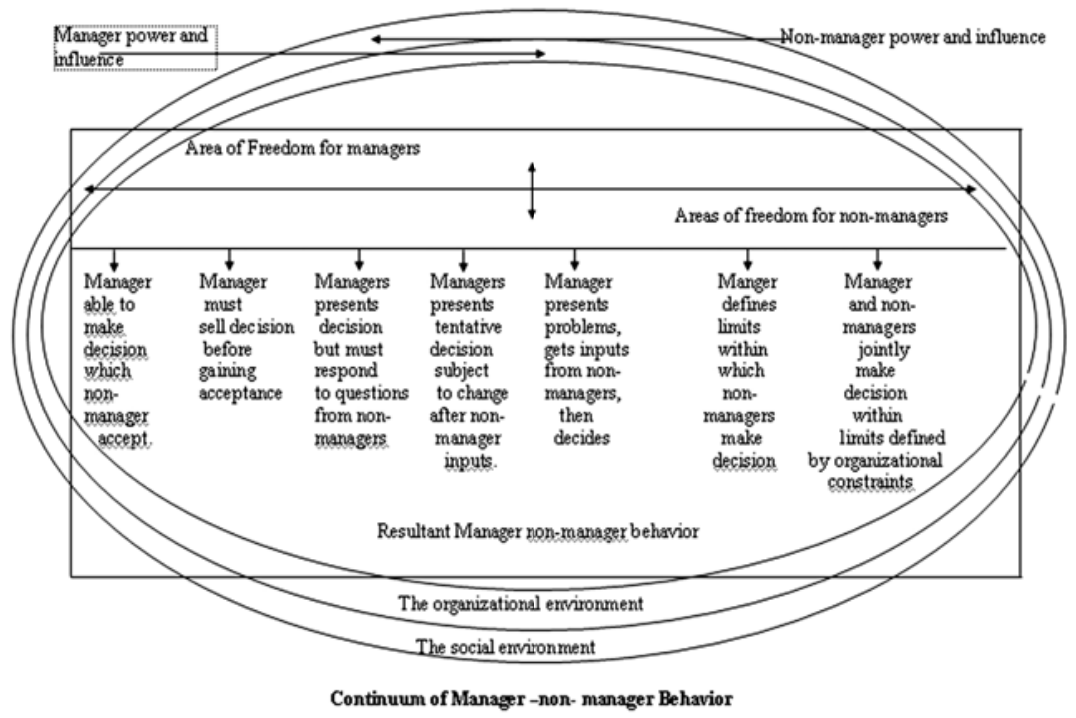

This theory recognizes that appropriateness of a particular style is dependent on the leaders, the followers and the situation. In the revision of continuum theory, interdependency of leadership style and environmental forces have been included in 1973 [Vide the modified diagram of leadership continuum in Fig.3]. This is due to the fact that environmental factors like labor unions, greater pressures for social responsibility, the civil rights movement, and the ecology and 
consumer movement challenge managers to make decisions or handle their subordinates without considering them.

To consider from Islamic perspective it seems that the highly boss centered style of leadership in the continuum, where the subordinates have no voice but to accept the managers' decision is against Islamic ethics; hence it is not supported by Islam. Other styles are the reflections of discursive and participative management, which are justified by Islam. (Ather, 2005)

\section{Islamic Model of Managerial Leadership}

\subsection{Rationale of Developing the Model}

A model has got lot of significance. It pictorially represents something for better understanding and communication of thoughts and ideas, which has got ever lasting impressions in the readers mind. Therefore, the authors believe that without developing a model the research on 'Managerial Leadership: An Islamic Perspective' cannot be well conveyed and convincing to the interested groups. Hence it is rationally justified to develop the following model.

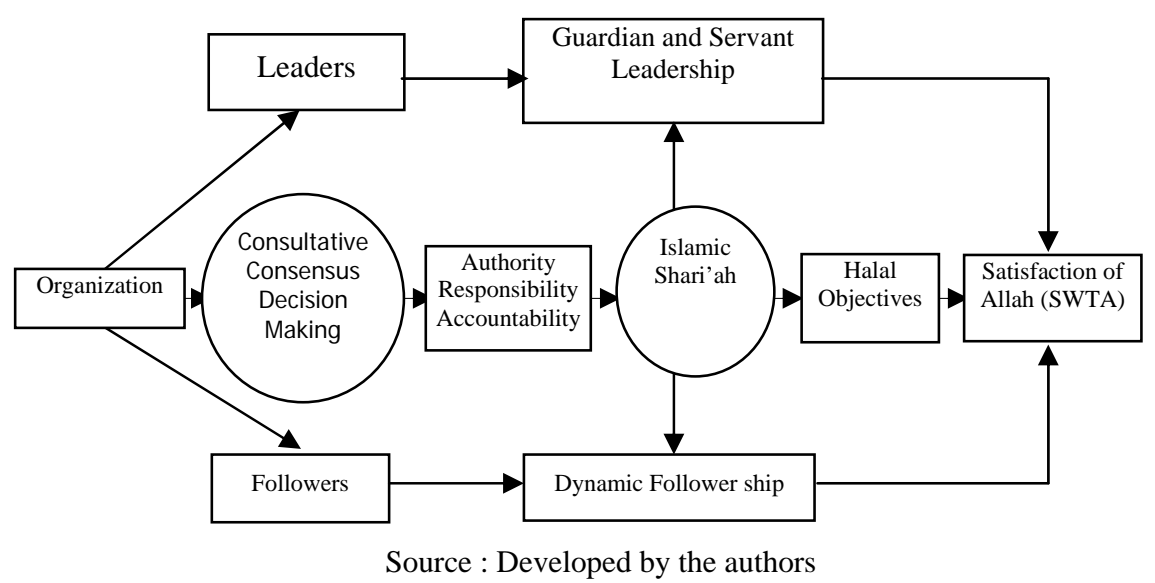

\subsection{Explanation of the Model}

On the bases of previous discussions, concepts and facets of Islamic Leadership, a Model of Managerial Leadership from Islamic Perspective has been developed (Vide-Fig. 4). Basic three elements of leadership as shown in the model are: Organization, Leaders and Followers. Leaders will take decisions consulting with the followers. Leaders will act, as both the servant and guardian leadership while the 
followers will show dynamism in their participation and action. Leaders will be gentle to the followers and they should never be harsh with them. Leaders must pass over followers' faults, if any, and ask for Allah's forgiveness. They must consult followers when necessary. After consulting leaders must decide and put trust in Allah (Swt).

The role of followers in Islamic leadership process will be positive. They will act as observers of men, women and things. They must be cooperative with their leaders. They provide necessary suggestions to their leaders thus contributing to decision-making. They also warn their leaders for their actions if necessary. The followers must withdraw their support if and when the leaders are seen deviating from the right path of Islam (Anisuzzman et al, 1996). Thus they will play the role of dynamic rather than blind followership.

The functions and operations of the organization must be guided and controlled by the rules of Islamic Shari'ah i.e. Qur'an, Hadith, Izma and Qias. Nothing will be considered which is not supported by Islamic Shari'ah. The leaders and followers both will be accountable for their responsibilities to the organization and Allah (Swt) as well. The objectives of Islamic leadership include both mundane welfare and eternal bliss. The ultimate objective of the Islamic Leadership will be attaining satisfaction of Allah (Swt) through fulfillment of organizational rational (halal) objectives.

\section{Concluding Remarks}

Nowadays, leadership is being considered as a key factor for the success of any organization. The Muslim managers of global business world must possess Islamic leadership skills to survive in the competitive market. In today's demanding and dynamic leadership requirement, managers who are incompetent in an organization must be willing to constantly upgrade their skills. There is no doubt that continuous efforts to acquire skills will lead a manager to become a successful leader. Teamwork under an effective leader is recognized as a vital force in achieving organizational goals and objectives. The success of a team is dependent on the group efforts under a team leader. Some very talented individuals are not good team members by nature in teamwork. A team member in an Islamic organization must be willing to sacrifice his opinion if needed for the greater interest of the team. For effective results, members of the team must be trained about Islamic values, ways of communicating within the team, behavior \& attitudes, and consensus formation. A manager having 
leadership qualities as laid down in Islam, is expected to combat any managerial challenges and complexities of the centuries ahead.

\section{References}

1. Al Qur'an

2. Al Hadith

3. AHMAD, A.B. RAFIQUE (2006), Leaders-Followers' Relation in Organizations: An Islamic Perspective, IIUC Business Review, Vol. 1, July 2006 PP.6-7

4. ALTALIB, HISHAM (1991), Training Guide for Islamic Workers, Published by the International Institute of Islamic Thought (IIIT), Herndon, Virginia, USA, PP.50-52, $130-135$

5. ANISUZZAMAN, M. AND MAJUMDER, M. Z. A. (1996), Leadership: Western and Islamic - A Conceptual and Explorative Study, published by Bangladesh Institute of Islamic Thought (BIIT), Dhaka, PP.6-7, 22-23, 41-45

6. ATHER, SYED MOHAMMAD (2005), Islamic Management and Business, Lecturer Materials for the Students of MBA Program, PP.35-37

7. ATHER, SYED MOHAMMAD (2006), Islamic Management - An Introduction and Its Contrasts to Traditional management, IIUC Business Review, Vol. 1, July PP.20-23

8. E. E. GHISELLI (1976), Exploration in Managerial Talent, s.l.:s.n.: s.d

9. GAVIN, J. F. (1976), A Test of Ghiselli's Theory of Managerial Traits, Journal of Business Research, PP.46

10. DAVIS, KEITH et al (2001), Organization Behavior, PP.385-386

11. KONTZ et al (1994), Management: A Global Perspective, 10th edition, PP..499

12. KOTTER, JOHN P. (1990), What leaders relay do, Harvard Business Review, May-June, PP.103-111

13. LUTHANS, FRED (1995), Organizational Behavior, Seventh Edition, Mcgraw Hill Inc. publication, New York, PP.379-453

14. MEREDITH et al (2000), Project Management - A Managerial Approach, 4th edition, John Wiley \& Sons, Singapore, PP.136

15. PATWARY, ENAYET ULLAH (2003), Leadership in Islamic Perspective, Executive Views, Vol. 2, International Islamic University Chittagong, PP.58 